\title{
Quality Management for Road Network Organizations
}

\author{
ESAT GASHI \\ Department of Construction Management \\ Faculty of Civil Engineering, University of Prishtina \\ Sunny Hill nn, Prishtina, \\ KOSOVO \\ HAJDAR SADIKU \\ Department of Construction \\ Faculty of Civil Engineering, University of Prishtina \\ Sunny Hill nn, Prishtina, \\ KOSOVO
}

\begin{abstract}
Road network organizations should recognize quality firstly as part of business competitiveness. Road network infrastructure in general are damaged due to lack of proper maintenance and lack of investments by the Governments. The growing importance of the quality question in road network organizations has led many executives to modify their business and quality policies. Quality Management System helps to enable this evolution through a combination of "soft" non-technological (culture, habits, management and leadership approach) and "hard" technological changes that can yield substantial quality and environmental improvements. The quality challenge must be a major source of managerial change. The article focuses on the need for new approaches in the quality management of organizations and describes the quality management process which organizations could exemplify for road network organizations. We develop a general model of quality management in road network which is presented at this paper. Lipovec's organizational theory is applied. An understanding of, and systematic and consistent implementation of quality management in practice will be of key importance to the future development of road network.
\end{abstract}

Key-Words: - Administration, dialectic system, innovation, road network, quality, quality management, Leadership

Received: November 14, 2019. Revised: March 1, 2020. Accepted: March 18, 2020.

Published: April 26, 2020.

\section{Introduction}

The road network worldwide consists of millions of kilometers of different categories serving for transportation of people and goods from one point - origin, to the other point - destination. Lot of new roads, motorways and corridor axes are under construction or full reconstruction aiming to to fullfill users requiremnts while using this network, easy ,safe and smooth for drive, with no traffic conjuction and easily to be accessed or departed from the origin or destination. To fullfill all said requiremnt and complying with safety restrictions imposed by local,regional and widely worldwide road authorities in one hand and budget restrictions on the other hand, brings road organisations to a difficult task to comply with technical and safety requirements and at the same time being profitable. Road network organisations like other bussiness models must comply strictely with Quality Management principles in order to meet the client satisfaction, keep uo to date all technical and safety parameters in order to be competetive in the market and satisfy finall user during the operations in this network. Characteristic for these most developed is the effectiveness and successfulness, that basis on the price, quality, uniqueness and choice of tendered. It is about the enforcement with the knowledge, creativeness, culture, where in its broadest meaning belongs also the permanent quality. The ability of competition with the world competitiveness also means the ability of competitiveness in the permanent quality development. It is possible to preserve the competitive advantage especially with the totality between the planning, administration, 
control and comprehension of entrepreneur operation content.

\section{Management and Quality Management}

In order to understand and further discover the connection between the concepts of quality management and consequently excellence, the basic terms in the mentioned fields need to be defined. In general, the authors define "management" mostly from a process viewpoint [1], [2], ,3], as the achievement of the goals of the social unit the term 'social unit' is used for any private or public organization in an effective and efficient way, through planning, organizing, leading, and controlling/checking the assets of the social unit. Many plans in different organizations in general are well prepared, but in the execution stage fails or do not complete on time, same case is with organizations dealing with projects in road sector too. This is because of insufficient control to identify problems and seek for potential solutions.

The European organizational theorists [4], defined management as an organizational function or process, which:

- Assures that the (technically divided) operations of specific individuals remain a part of a unified process of achieving the objectives of the business (the technical aspect of management);

- Receives its task and authority for the execution of the task from governance as its executive and confidential body (the social aspect of management); and

- Executes its task with the help of other people in the process of planning, delegating, carrying out, coordinating and controlling, as initiated in governance (the process aspect of management).

On that basis Rozman developed a new, more systematic and integrated scheme of the (governance)-managerial process [5], [6]. $\mathrm{He}$ claimed that improvements in the management process must be made in the fields of organization and leadership and that the individual levels must be separated from the level of a social unit. Besides management, governance is added because the activities in any social unit are started by governance (representing the owners) and are continued in management process. Since the governance processes are not dominant in public administration and the stress will be on management in public administrations organizations, the term 'management process' will be used for the Quality Management Model for Road Organizations.

Management process therefore consists of planning and controlling/checking business at the social-unit level (phases 1 and 5) where the effectiveness of a social unit is the goal worked towards. At an individual level, there are three processes: planning the organization, actuating the organization, and controlling the organization (phases 2, 3 and 4), through which rational achievement of a social unit's goal(s) should be achieved. All mentioned phases must be performed before (1 to 3 ) or after (4 and 5) the execution phase. We understand the same steps in environmental management as a part of environmental business excellence can be applied.

The second important concept that has to be described and positioned within the management process is Quality Management (QM). The definitions of $\mathrm{QM}$ are numerous and, in general, most of them are oriented in satisfaction of the end user for which the system is composed or care about the customer. The concept of QM is also often connected to or substituted for other similar phenomena such as business quality, business excellence, etc. Quality outcomes are those that balance the performance objectives of the present with the needs and expectations of the future [9]. Among global corporations today, these kinds of outcomes result from profound changes in strategic thinking, leadership and management of business, some of which include:

- Enterprise (system) thinking, shifting from managing the internal aspects and direct links of the corporation to assuming broader responsibilities for the entire enterprise - i.e. the practices of suppliers and their suppliers, customers and their customers, stakeholders and those who dispose of or recycle/refurbish a product at the end of its useful life.

- Visionary leadership, having visionary and principled leaders with the knowledge, analytical skill, creativity, and inspiration 
to craft strategies and initiatives, lead change, and create breakthrough solutions to meet the needs of the global business environment, both today and tomorrow.

- Strategic thinking, transforming the strategic management systems (SMS) from one that focused on producing products and services, satisfying customers, and generating profits to a richer framework that connects all constituents via an interactive system focused on creating value through sustainable solutions and total satisfactions.

- Product and technological innovation, developing new technologies and products that create solutions depends on the intellectual capital of the organization and its systems and processes for turning opportunities and challenges into sustainable success [9].

3 Quality Management Model

The management process and quality management can be connected in a manner that must be understood, if a social unit is to create a basis for excellence. This means that care for all stakeholders must be incorporated into each phase of the management process. Different indicators (objectives) need to be determined in both planning phases (for business and organization). The processes of acquiring, motivating, rewarding and communicating with each stakeholder group has to be executed in the 'actuating the organization' phase.

Controlling the business and controlling the organization provide opportunities to check whether the objectives have been met and to seek potential discrepancies between the planned goals and actual results. If there are gaps between the planned and actual results, management need to detect for causes and solutions of the created problem. This brings the management process to the planning phases again and a new cycle of management process can be started for the next short or long-term period. The final field to be discussed is the field of excellence and how it relates to the management process. Excellence in general is defined by many authors as "exceeding the average" or "exceeding expected quality" or "something above quality". To be more precise: based on the management process as discussed above, excellence can be understood as a function of both efficiency and effectiveness. However, the execution cannot be efficient, if there is no organization in the sense of setting up relationships within and outside the social unit, through which the different groups of stakeholders are involved in the social unit's functioning.

Efficiency can therefore be assured through planning the organization, actuating the organization, and controlling the organization the 'classical' management process, consisting of planning, organizing, leading and control/checking was and still is a basis of existing management/excellence models. This presents a main barrier to a more scientific approach. The proposed management model for road network organizations is based on management process with 5 phases [7] and each of them has to be executed taking all the social unit's stakeholders into account. The detailed and sound elaboration of the model offers an important contribution to the organizational science. The model presented in figure 1 , is divided into two main sections. 


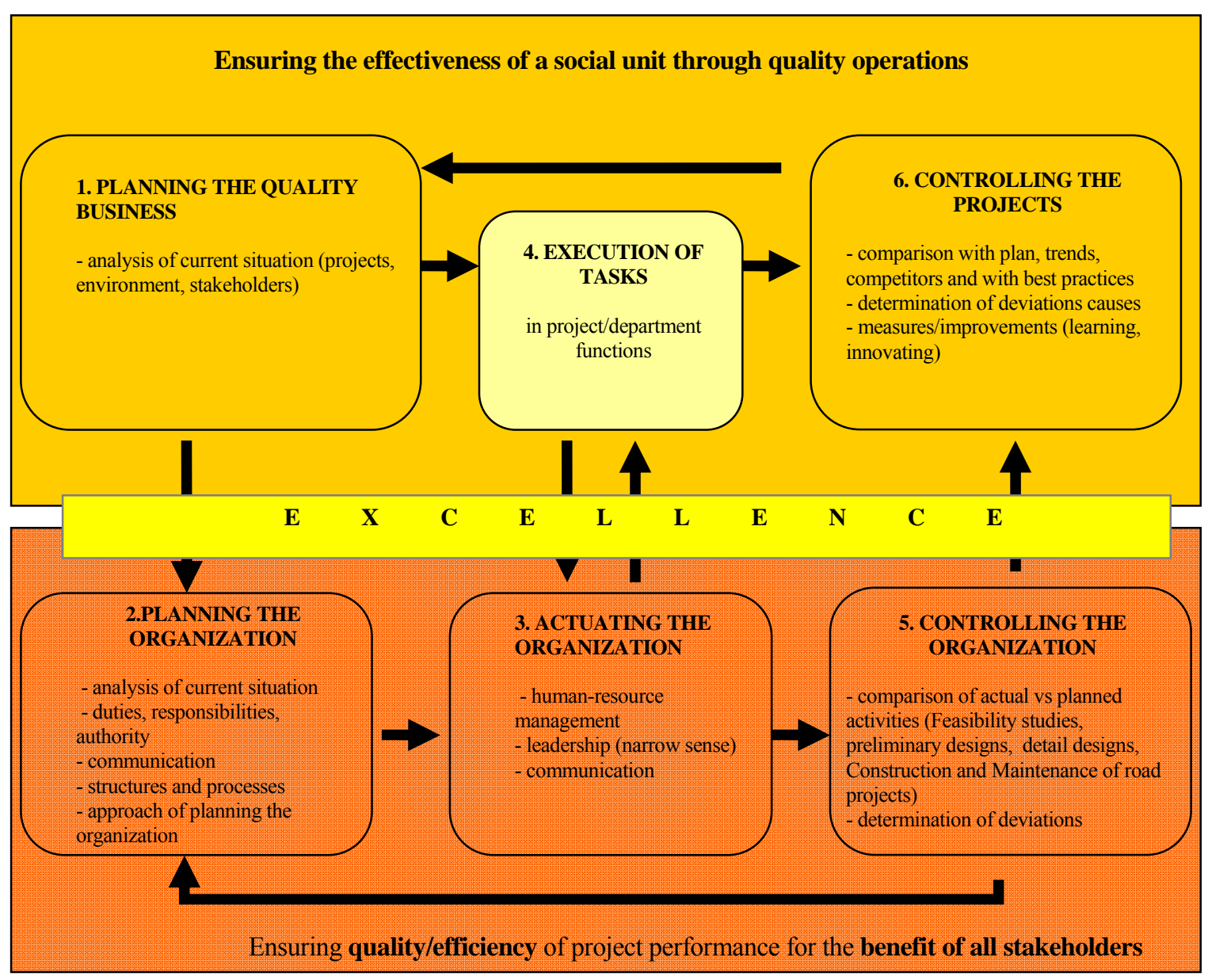

Figure 1 . The quality management model road network organizations

The first section covers management functions, which relate to the operations of a social unit planning and controlling the business and relate to effectiveness through socially responsible business. The second section represents the individual level employees and other stakeholder groups and comprises the functions of planning the organization, actuating the organization, and controlling the organization. Further, each of the five phases of the management process within the model is broken up into several approaches. These approaches represent the basic steps each manager should carry out in order to implement systematic, requisitely holistic,

professional and transparent management and consequently to assure efficient achievement of the social unit's goals. This does not rule out more detailed or additional approaches being determined for an organization or organizations of a specific type from the public or private sector.
At the same time, it is anticipated that all functions and therefore all approaches are implemented in a socially responsible manner i.e. taking all stakeholders into account.

The quality management model for the organizations dealing in road sector is similar with quality management models of other organizations from the industry and economy sector. This model is part of the general model which has been presented in other publications and is based on the research of 120 European organizations from different branches of Industries and Economy. This research analyzed reaction of different organization into the overall performance by applying principles of the quality management as presented in figure 1 .

The dimension is most prominently marked by the indicator Quality management measures are planned, executed, controlled and enhanced incessantly, in which the highest factor loading is obtained. The Cronbach reliability coefficient (alpha) 
value, which measures the reliability of a measuring instrument, is 0.9 , suggesting the appropriateness of the choice of indicators. The indicator Leadership quality in general was determined by the following indicating devices: encouraging and promoting autonomy at work, encouraging and promoting employee co-operation in decision making and identifying the needs for organizational changes.

Table I. Leadership - factor loading after orthogonal rotation

\begin{tabular}{|l|c|c|}
\hline & $\begin{array}{c}\text { Leadership } \\
\text { in the area } \\
\text { of QM }\end{array}$ & $\begin{array}{c}\text { Leadership in } \\
\text { general }\end{array}$ \\
\hline $\begin{array}{l}\text { QM measures are planned, executed, } \\
\text { controlled and enhanced incessantly. }\end{array}$ & 0.86 & 0.14 \\
\hline $\begin{array}{l}\text { Leaders assess the efficiency and } \\
\text { effectiveness of QM business } \\
\text { processes. }\end{array}$ & 0.85 & 0.16 \\
\hline $\begin{array}{l}\text { Leaders encourage launching } \\
\text { initiatives, searching new } \\
\text { opportunities and solutions for } \\
\text { tackling quality problems. }\end{array}$ & 0.80 & 0.21 \\
\hline $\begin{array}{l}\text { Leaders efficiently inform their } \\
\text { employees about quality issues. }\end{array}$ & 0.78 & 0.25 \\
\hline $\begin{array}{l}\text { The management has a clear vision, } \\
\text { strategy and objectives concerning Q } \\
\text { M }\end{array}$ & 0.70 & 0.20 \\
\hline $\begin{array}{l}\text { Leaders encourage and promote } \\
\text { autonomy at work. }\end{array}$ & 0.19 & 0.95 \\
\hline $\begin{array}{l}\text { Leaders identify the needs for } \\
\text { organizational changes and are first } \\
\text { to opt for changes. }\end{array}$ & 0.13 & 0.94 \\
\hline $\begin{array}{l}\text { Leaders encourage and enable their } \\
\text { employees to co-operate in decision } \\
\text { making. }\end{array}$ & 0.33 & \\
\hline
\end{tabular}

The indicator Leaders encourage and enable their employees to co-operate in decision making has a lower factor loading and thus a lower contribution to this dimension. The Cronbach coefficient value is 0.9 , therefore, the indicators serve as a reliable measuring instrument for assessing leadership in general. Based on the reliability coefficients, the selected indicators can be used for computing indicators, namely the average value of each indicator, pertaining to a certain dimension as shown in Table II.
Table II. Descriptive statistics of leadership indicators and dimensions

\begin{tabular}{|c|c|c|c|c|c|}
\hline Leadership & $\mathrm{N}$ & Min & Max & $\begin{array}{c}\text { Arithm } \\
\text { etic } \\
\text { mean }\end{array}$ & $\begin{array}{l}\text { Stand } \\
\text { ard } \\
\text { devia } \\
\text { tion }\end{array}$ \\
\hline $\begin{array}{l}\text { Quality management } \\
\text { measures are planned, } \\
\text { executed, controlled and } \\
\text { enhanced incessantly. }\end{array}$ & 110 & 1 & 5 & 3.35 & 1.21 \\
\hline $\begin{array}{l}\text { Leaders assess the } \\
\text { efficiency and effectiveness } \\
\text { of quality management } \\
\text { business processes. }\end{array}$ & 110 & 1 & 5 & 3.16 & 1.12 \\
\hline $\begin{array}{l}\text { Leaders encourage launching } \\
\text { initiatives, searching new } \\
\text { opportunities and solutions } \\
\text { for tackling quality } \\
\text { problems. }\end{array}$ & 110 & 1 & 5 & 3.22 & 1.14 \\
\hline $\begin{array}{l}\text { Leaders efficiently inform } \\
\text { their employees about } \\
\text { quality issues. } \\
\end{array}$ & 110 & 1 & 5 & 3.18 & 1.11 \\
\hline $\begin{array}{l}\text { The management has a clear } \\
\text { vision, strategy and } \\
\text { objectives concerning quality } \\
\text { management. }\end{array}$ & 112 & 1 & 5 & 3.71 & 1.13 \\
\hline \begin{tabular}{|l|}
$\begin{array}{l}\text { Leadership in the area of } \\
\text { quality management }\end{array}$ \\
\end{tabular} & 113 & 1 & 5 & 3.33 & 0.98 \\
\hline $\begin{array}{l}\text { Leaders encourage and } \\
\text { promote autonomy at work. }\end{array}$ & 101 & 1 & 5 & 3.89 & 0.88 \\
\hline $\begin{array}{l}\text { Leaders identify the needs } \\
\text { for organizational changes } \\
\text { and are first to opt for } \\
\text { changes. }\end{array}$ & 110 & 1 & 5 & 3.91 & 0.86 \\
\hline $\begin{array}{l}\text { Leaders encourage and } \\
\text { enable their employees to co- } \\
\text { operate in decision making. }\end{array}$ & 111 & 1 & 7 & 3.65 & 1.01 \\
\hline Leadership in general & 111 & 1 & 5 & 3.81 & 0.83 \\
\hline
\end{tabular}

As it can be seen from the presented tables, the enterprises that positively or favorably assessed Leadership in general, normally positively assessed Leadership in terms of quality management.

\section{Conclusions}

Extensive researches were carried out lately in the field of Quality Management models aiming to tailor fit for purpose for different organizations. Knowing that each organization is different from the others preparing an adequate model of the Quality Management for such organizations is really challenging. This is because modifications and changes are hardly accepted from people especially from the Leadership. If Leadership is convinced that changes in the organizations are needed for the sake of the quality improve, then second and third layer of the employees easily will accept such changes. Such 
changes must aim improvement of final product or service satisfying end user or client. Organizations dealing with road sector are composed from different departments dealing with feasibility studies, planning, implementing and maintenance of the roads, in the government, regional and local level. All thus levels contain leaders, managers and other employees which need to be continually improved in line with accepted model of Quality Management of that organization. One of such models is presented in this paper. As it is presented with two other tables if the leadership of the organizations accepts modifications aiming continuous improvement, they will steer the rest of the organization hierarchy, level II and level III managers and employees to easierly accept such changes. The easiest way to implement such changes is through education.

When the human part of organization is well educated and trained, it is expected that final product or service will be in line with end user expectations and beyond.

Continuous improvement is paramount for quality improvement of the product or service of one organization.

Quality management model is based on grounds of theoretical findings of the authors and it is the central part of this contribution. It is divided into two sections: the management functions which are in relation with operation of the company as a whole (planning and controlling the business) and at the level of individuals (employees and other group members), which includes the functions of planning the organization, actuating the organization and controlling the organization. The model defines the approaches for each function that should be implemented if a company wants to be perceived as quality successful.

Management should not focus on short-term benefits, but on long-term consequences of quality aimed at long-term efficiency and effectiveness of the company's business and quality activities during the process of company re-engineering or renovation.

\section{References}

[1] Daft, R. L. 2007. "Understanding the Theory and Design of Organizations". Mason: Thomson South-Western.Friedman, M. and Freedom. Chicago: University of Chicago Press.
[2] Rozman, R., Kovač, J., Koletnik, F. 1993 Management". Ljubljana: Gospodarski vestnik.

[3] Schermerhorn, J. R., Jr. 1999. „,Management” New York, John Wiley \& Sons.

[4] Lipovec, F. (1987) „Razvita teorija organizacije” Maribor: Založba Obzorja.

[5] Rozman, R., Sitar, A. S. 2007. "Impact of Organization on Organizational Learning and Knowledge Management". Vienna: 23rd EGOS Colloquium, Beyond Waltz - Dances of Individuals and Organization. pp. 1-19.

[6] Tomaževič, N. 2010. "Družbena odgovornost kot temelj odličnosti javne uprave". Doktorska disertacija. Ljubljana: Univerza v Ljubljani, Fakulteta za upravo.

[7] Gashi. E, Kralj. D „Quality of Road Network in Kosovo as a Consequence of Administration Innovating." 5 WSEAS Congress - Malta, September - 2012. pp. 24-31.

[8] Gashi. E, Kralj. D,, Economic efficiency in road network as a result of quality management system'.' I st Albanian Conference on roads Tirana, September, 2012. pp 1-7.

[9] Hart, S.L. 2007. "Beyond Greening: Strategies for a Sustainable World", Harvard Business Review on Green Business Stratagems Press, Boston, MA. pp. 99-125.

[10] Gashi.E, Kralj.D.,, Innovation of Quality Management in Engineering Projects', International Journal of Applied Engineering Research ISSN 0973-4562 Volume 12, Number 22 (2017) pp. 12899-12905,

[11] Nadezda Z., Yuri M., Andrejs R.,, The General Principles of the Transportation Simulation Model Development and Validation" WSEAS Transactions on Systems and Control, Volume 15, 2020, pp. 81-92 